\title{
英文報告
}

\section{Executive Director's Annual Report, 2006}

\section{Yoshinobu TOBO}

As this is the last edition upon which this executive body will report, we would like to write about the changes during these four years in the administration of the Japan Society of Christian Studies. Since entering the twenty-first century, we first reconfirmed the fundamental stance this Society takes regarding our activities. This Society holds to aspects that maintain a tense internal relationship. One is the aspect to treat Christianity as an object of academic study as we can see in the name of the Society "the Japan Society of Christian Studies." The other aspect is to speak from theology which is subjectively the study of the Church, and is clear in the name of our journal "Japanese Theology." This is significant for our Society. Our theme for the symposium at our 2006 Conference is "Church, Theology, and Biblical Studies," and this shows our fundamental stance. This stance continues as this Society's essential characteristic and we hope to continue it into the future as well.

When we started to take the role as the administrators for this Society, we had few young scholars. However, with the help of other members' instructions and guidance, the number of young members in their $20 \mathrm{~s}$ and $30 \mathrm{~s}$ have increased. Because of this, we have more research presentations at conferences, so we were asked to accommodate more presentations at each conference site. This is the same in our academic journal. There are more papers submitted to the journal recently, leading us to develop indicators to decide how many articles may be chosen. It is hoped that the study of Christianity and theology will continue to thrive in twentyfirst century Japanese society where globalization is observed even in a cultural sense. We also hope that our research will be transmitted from Japan to the world.

We have also pursued information transparency by making clear in writing our administrative regulations, bylaws, administrative guidelines and other traditions and by publishing them in the journal. This effort is so everyone can understand the administration of the Society. In the academic world, academic succession and instruction, or training, are essential. At the same time, it is necessary for 
researchers to be shown and instructed in how to be an active part of the activities of the Society. We hope that the members will take an active role in our Society.

As today's world is undergoing rapid development in information technology, our Society has digitalized data from paper-based information. When we started to take our role as administers for this Society, we received many boxes of papers. However, from now on each administrator will take over the data in digital form, simplifying the process. In addition to this, our Society has its own web site from which people can download application forms. Furthermore, people can email the Society office, which allows us to exchange information quickly. In terms of how we should proceed with and incorporate this information technology requires careful consideration and discussion, especially regarding protection of privacy.

As we look back on the research presentations at the conferences held by each branch chapter, we observe diverse areas of research, including Christian studies and theology. We saw exhaustive individual studies, interdisciplinary studies, historical research, and research that includes the challenges and issues that we face today. This diversity is the characteristic that we embrace as the Japan Society of Christian Studies. Although there must be commitment to other individual academic disciplines, we hope to see more presentations from the field of Biblical Studies.

Our 53rd academic conference was held on September 23rd and 24th, 2005, at Kwansei Gakuin University. The open lecture was entitled "Christological Monotheism: Subconscious Aggression and The Birth of Peace in Primitive Christianity," Dr. Ulrich Luz gave a very meaningful and interesting lecture. The translator was Prof. Manabu Tsuji. The symposium was titled "The Realization of Peace: Issues in 21st Century Theology," with Prof. Kenji Kanda chairing, and panelists Prof. Teruo Kuribayashi, Prof. Sadamichi Ashina, and Prof. Hisako Kinukawa. There were 35 research presentations.

The activities the branch chapters of the Society were reported as follows. The Hokkaido Branch had its meeting on July 17th, 2006, at Asahikawa Palace Hotel. They had five research presentations. The Tohoku Branch met on June 17th, 2006, at Miyagi Gakuin Women's University. There was an open lecture entitled "Jan Laski and the Lord's Communion: Considerations from the Bylaws of the London Church" by Prof. Akira Demura and there were six research presentations. The 
Kanto Branch met on March 17th, 2006, at Rikkyo Univeristiy with six research presentations. The open lecture titled "The Glory and Failure of Kirishitan music," by Prof. Tatsuo Minagawa followed by response by Prof. Teruhiko Nasu. The Kinki Branch met on March 15th, 2006, at Doshisha University with 15 research presentations. An open symposium was held titled "Recommendations from Japanese Religions to Monotheism." Prof. Tetsuo Yamaori was invited as a lecturer, and Prof. Koichi Mori, Prof. Izaya Tejima and Prof. Tetsuo Yamaori were the panelists. The Kyushu Branch had its meeting on March 27th, 2006, at Seinan Gakuin University with six research presentations. An open symposium was held with the theme "Life and Ethics," and Prof. Naoto Kawano, Prof. Koji Ueda and Prof. Karen Shaffner were the panelists.

Having served as administrators for activities of this Society, we are truly appreciative of the cooperation of a great number of individuals and research organizations.

(Translated by Paul Tsuchido SHEW) 